\title{
1. The meaning and scope of business ethics in Islam
}

What are the common business ethics theories? Can these theories provide practical insights into ethical misconduct? Are there ethical guidelines that could prevent fraudulent behavior? Does Islam share a similar outlook on ethics with other monotheistic religions, especially Christianity and Judaism? Does the Islamic faith address ethical business issues? Does it provide guidelines that are sufficient and practical for preventing ethical misconduct? What are the implications of Islamic prescriptions for business people in a globalized world? These and other issues are addressed in this chapter. The objective is to identify, define, and present Islamic business ethics for business people and researchers alike. The chapter includes the most relevant early Islamic perspectives on market interactions and dealings. Furthermore, it sets the stage for identifying how to engage in purposeful conduct in the face of rising market entrapments and material allurements in the marketplace.

The intensity and frequent occurrence of fraud and corruption in the marketplace in recent decades has accentuated the necessity and importance of delineating, clarifying, and identifying business ethics. Policymakers and business people across the globe have questioned increasing incidents of corruption and the persistency of deception despite stiff regulations and the rising vigilance of public agencies, especially in the Western world. The severity of the consequences of corruption, for both organizations and society, has encouraged market regulatory and civic actors to search for a suitable response to the rising challenges of corporate scandals and fraud.

Due to the failure of these actors to limit the increase or spread of corporate scandals and fraud, researchers throughout the world have pondered the possibility that spiritual and religious instructions and traditions may be vital sources in helping minimize or discourage corruption at the individual and organizational level and could generate insight on how to deal with chronic business ethics violations. While the tenets of Christianity (e.g., Abela, 2001; Emerson and Mckinney, 2010; Karns, 2008; Lee, McCann, and Ching, 2003) and Judaism (e.g., Lewison, 1999; Pava, 1998; Tamari, 1991) have been intensively and systematically debated 
in business ethics and organization literature, studies focusing on Islamic perspectives and Islamic prescriptions in the marketplace are at best scattered and scarce.

Like Christianity and Judaism, Islam tackles market issues and market behavior both directly and indirectly. Some of these issues are business specific and have direct implications. For example, the saying of the Prophet that "Deception and fraud may sell the goods but lose the blessing" (quoted in Al-Ghazali, 2004, p. 30) focuses directly on business interactions and, therefore, its implication for broader business conduct is easy to grasp. On the other hand, some instructions are general in nature, but nevertheless have implications for business affairs. A good example is the Prophet's saying, "He who cannot keep his trust has no faith and he who cannot fulfill his promise has no religion" (quoted in Al-Ghazali, 2004, p. 35). Whether instructions are business specific or are general, they have been analyzed and addressed by early Muslim scholars since the inception of Islam. Both jurists and researchers have highlighted the spiritual and social aspects of these prescriptions, enabling believers to understand that behaving in ethically condoned manners in the market is expected of them.

\section{WHAT ARE BUSINESS ETHICS?}

Any understanding of business ethics cannot be realized independent of the general meaning of ethics. Indeed, articulating and exploring the essence of ethics is essential for comprehending the applicability of business ethics in any society. Though ethics is a relative term, scholars and practitioners alike agree that ethics denotes a society's perception of what is right or wrong. Viewed in this general term, tradition, society's evolution and interaction with the outside world, economic conditions and the state of the economic system, government policies, and religion all shape the meaning of ethics. However, while there are certain core issues in ethical systems that are shared across groups and societies, there are others that are cherished by a particular culture and which are deeply and or widely held regardless of time or location.

Shaw (2008, p. 5) argues that ethics "deals with individual character and the moral rules that govern and limit our conduct." Hartley (1993, p. 3) defines ethics as "standards of right conduct." While Islamic tradition and thinking underscores right conduct, it simultaneously highlights the benefits to society as the measure for judging whether a conduct is right or wrong. Naqvi (1981, p. 18) suggests that ethics epitomizes the "common values of a society and determine[s] the preference structures of the members of that society." The linkage between an individual and his/ 
her community is manifested in ethical responsibility where self-interest is sought to be in harmony with that of the society. This has always been the concern of Islamic jurists, informed ordinary citizens, and enlightened rulers. Whether a sound balance between individual and community interests can be achieved depends primarily on effective utilization of reason and familiarity with and internalization of religious instructions.

In Islam, ethics is the foundation of deep faith, societal prosperity, and individuals' living standards (see Al-Mawardi, 2002 for detail). Without ethical conduct, prosperity and the well-being of individuals are impossible to achieve. That is, good ethics are a prerequisite for achieving a sustainable economy and social goals. The Prophet asserts that good ethics and generosity lead to "complete faith." In terms of economic development, the Prophet articulates the link between ethics, business, and prosperity stating, "Good ethics and being good to one's neighbors contributes to the prosperity of cities and increases development" (quoted in Al-Mawardi, 2002, p. 383). Al-Mawardi (2002) reported that "He who displays bad ethics, his earnings will be severely curtailed." Though these judgments and instructions underscore the centrality of ethics in economic activities and societal welfare, early Islamic thinkers recognized that ethics cannot exist independent of sound judgment, responsible thinking, and reason.

Guided by Quranic instructions, Muslims thinkers understand that people differ in their conduct and that sound reason rather than lack of it allows people to distinguish what is right from what is wrong. The Prophet Mohamed observes, "Reason is a light in the heart; it differentiates between right and wrong" (quoted in Al-Mawardi, 2002, p. 15). The Quran (17:84) states, "Everyone acts according to his own disposition, but your Lord knows best who has the right guidance." Therefore, Islamic instructions recognize that differences in ethical behavior, commitment, and conduct are a natural propensity and that only through reason are individuals able to grasp what is beneficial and what is harmful for self and society. Al-Mawardi (2002, p. 11), a jurist who died in 1058, made a sound argument when he stated that "for each virtue there is a base and for each ethic there is a stream, and the foundation for both is reason." This dialectic relationship between ethics and reason emphasizes that ethics from an Islamic perspective is defined as "specified rules that govern individuals and organizational conduct and seek to ensure generosity, transparency, and accountability in behavior and actions, while safeguarding societal interests" (Ali, 2011, p. 20). These aspects are necessary for understanding the concept and principles of business ethics in Islam.

Abu Talib al-Maki (1995, died 996), a jurist and Islamic thinker, recorded certain business incidents and treatises that demonstrate how business ethics in Islam were much broader in his time than the narrow meaning 
attached to business ethics in today's world. Al-Maki (1995, p. 554) argued that any trade or manufacturing activity that is inconsistent with the teachings and instructions of sanctioned ethics is not permissible. He advised business people that if they were in doubt as to the ethics of their conduct then they should avoid any action, irrespective of the gain that might be obtained. He stated, furthermore, that if all people strictly observed what is permissible then there would be no differences in behaviors and desires and, therefore, there would be no need for government or religious guidelines to enforce order and articulate the desired behavior (p. 548).

Like the general term ethics, business ethics is variously and often vaguely defined. Hooker (2011, p. 2) regards business ethics as a "conceptual framework for making defensible business decisions that consider all stakeholders." DesJardins (2010, p. 9) views business ethics as "those values, standards, and principles that operate within business." Similarly, Parboteeah and Cullen (2013, p. 5) define business ethics as "the principles and standards that guide business." The standards and principles, however, may differ from one culture to another. For example, the emphasis on maximizing profit in North America may not have the same priority in East and South Asia.

Islamic business ethics are far reaching, as it sets the standard for going beyond what is generally accepted in the marketplace. To adequately present how business ethics in Islam are broader than the currently prevailing perspectives promoted in Western teachings and practices, a reference to some commentaries and incidents which took place during the first seven centuries of the Islamic civilization is essential. These commentaries capture the spiritual bent and morality of the time, but have relevance to business practices in today's world. Below are selected incidents that Al-Maki reported, which demonstrate the wide domain of business ethics.

\section{The Ethics of Selling}

Al-Maki (1995) showed the contrast between a good seller and the best seller. He reported that years before sellers had two books for those who bought on credit (p. 518). One of these books had no title and was specifically designed for those buyers who were poor and needy. This was because those who were in distressed circumstances would eye certain goods or produce they liked to eat but could not afford to buy. If a needy customer said to the good seller, "I need to have five or ten kilos of this, but I do not have money," the seller would reply, "Take them and when you earn enough then pay me." The seller would write the name of that person in his book, anticipating that someday the buyer would be able to pay him for the goods. However, the best seller would neither write down the name 
of the poor person in his book nor treat the total amount as debt. Rather, the seller would say, "Take what you need and pay me only when you are capable. Otherwise, you are free of any obligation."

\section{The Ethics of Contracting}

Al-Maki (1995) reported that when a tailor came to Ibn Mubarak (Islamic scholar, born around 726) and informed him that he could make suits for the agents of the ruler and asked, "Does that make me one who enables oppressors?" Ibn Mubarak replied, "It makes you an oppressor, not an enabler. The enablers are those who sell you the needles and threads" (p. 503).

\section{The Ethics of Social Responsibility}

Al-Maki reported that when Sari Al Sagdi (Islamic scholar) was sitting one night he was informed that a fire had been set in the market and had burned his store (pp. 91-2). On his way to the market, he met a group of people who told him that other stores had been destroyed in the fire but not his. His initial response was, "Thanks be to God." But he then pondered what he had said and thought, "I thanked God for the safety of my property but did not care about others whose properties were destroyed." So, he distributed everything that was in his store as a charitable act to erase his sin.

\section{The Ethics of Making Profit}

Abu Talib Al-Maki (pp. 508-9) recorded that Sari Al Sagdi bought a bin of almonds for 60 dinars and wrote in his account that the profit would be three dinars. The market price, however, increased to 90 dinars for a bin of almonds. A market agent stopped by and expressed interest in buying the bin of almonds and asked its price. Al Sagdi informed him that it would be 63 dinars. The agent told him that he would buy it for 70 dinars. But Al Sagdi refused and insisted on selling it for 63 dinars (to avoid charging more than what he originally thought was fair). However, the buyer refused to pay less than 70 (to avoid making a large profit margin). So, no transaction took place.

The above incidents demonstrate that business ethics in Islam has a much broader reach than the common concept of ethics in today's capitalism. In the market economy, meeting the requirements of the law and acting accordingly is often considered sufficient. However, there are many issues that are not addressed in the law and the legal system cannot take 
into account all market concerns and behaviors in a dynamic and ever changing business environment. In addition, on some occasions, a business transaction may not actually be harmful to any individual, but from the perspective of an individual or as a spiritual concern, the act may be considered unreasonable, as in the case of selling the almond bin at market price in the incident above. Even when business ethics includes the interests of all stakeholders, it is impossible to account for all the concerns and priorities of those involved in the marketplace. This is why business ethics in Islam has a broad reach; it goes beyond material gain, intention, and utilitarian perspectives. As we discuss in the chapters that follow, business ethics, in the context of Islamic teaching, is molded by spiritual concerns, depth of faith, and one's position and role in this world. The interplay of all these factors produces an outlook that encompasses more than mere material and legal considerations.

\section{THEORIES OF BUSINESS ETHICS}

Scholars in the field of business ethics have debated the necessity of having an appropriate measure for judging whether market behaviors and actions are right or wrong. While most of the debate has taken place in the last few decades, scholars have explored various frameworks and perspectives going back to the Greek civilization or the Age of Enlightenment in Europe. In their quest for theory development, classical philosophers and scholars have sought answers from the past to critical questions related to ethical obligations. This does not mean that contemporary scholars have failed to produce appropriate answers and have had to look at history to address a modern dilemma. Rather, it represents an acknowledgment of the thoughtful contributions of civilization and the relevancy of classical philosophical thinking to contemporary matters. Indeed, philosophical perspectives, across centuries, have often been found to be useful in answering concerns and subject matters essential for any functioning society. The philosophical perspectives, however, often differ in tackling matters related to how people should conduct their lives and their responsibility toward society.

Over the years, scholars have recognized three major business ethics theories. These theories vary in their reasoning and conclusions, but all seek to enlighten decision makers and ordinary citizens alike on what is considered suitable for dealing with human behaviors and dilemmas. In the context of the marketplace, these theories attempt to answer what a business actor ought to do in various business circumstances. The three perspectives that guide business actors are: teleological (consequences-oriented), deontological (duty-based), and virtue ethics. Below is a brief description of each. 


\section{Teleological (Consequences-Oriented)}

This particular approach underscores the significance of the output in deciding if an act is preferable or not. The word teleological is derived from the Greek word telos meaning goal or purpose. Whether a business decision is judged to be ethical depends primarily on the outcome. This approach encompasses two major sub theories: egoism and utilitarianism. Egoism treats any action that serves one's interest as ethical. A person, according to this view, is driven by whatever is deemed important to advance his/her interest for the foreseeable future.

Utilitarianism theory states that any act that leads to the greatest good for the greatest number is acceptable and therefore ethical. Implicitly, utilitarianism justifies the means, as long as the results are considered good. While this theory has many shortcomings, the most alarming one is that powerful actors, be they in the market or other domains, may use their supremacy to legitimize their actions, though the means to achieve them are horrible. Even if we assume that mechanisms exist to prevent the powerful from exercising undue influence, there are certain acts, as we see later, that should not be undertaken irrespective of the outcome. Furthermore, a core issue in utilitarianism is that acts which do not benefit the greatest possible number are judged to be bad. Advocates of utilitarianism have not provided adequate mechanisms for documenting the greatest number of gains in their equitable share of the resulting benefits. Likewise, no act is ever right or wrong in all circumstances; that depends on consequences (DesJardins, 2011). The problem that one might face is how to judge whether an action is bad or good. This requires having agreed upon standards for determining if an outcome is bad or good. Standards, however, are different among individuals and in a larger community, or in a globalized world, this becomes highly problematic.

DesJardins (2011) suggested that the most efficient way to measure benefits to the greatest number is found in the principles of free market capitalism. He argued that competition among rational and self-interested individuals is certain to lead to the greatest overall good. This, however, is mere speculation as events in the global economy have repeatedly demonstrated that the common scenario is that a few powerful actors take advantage of the market and consequently reap the economic benefits for themselves. In addition, these actors, according to many critics, use their economic positions to influence government decisions and politicians. That is, in the real world a purely free market economy is far from a certainty. Under such conditions, generating greatest benefits for the greatest number, as envisioned by utilitarianism, is difficult to realize. To counter such problems, Micewski and Troy (2007) proposed that self-interest in 
business should be tempered by moral duty and the rights of business executives and their self-interest must end where the rights of other stakeholders begin. In that respect, in 2005 (see Ali, 2005), we underscored the importance of character and credibility of market actors in sustaining market stability and emphasized that the prosperity of business people is highly interwoven with the interests of the community.

\section{Deontological Ethics (Non-Consequential)}

In contrast to the teleological premise, deontological ethics (deriving from the Greek word deon or duty) places emphasis not on outcome but on certain duties and responsibilities. Intentions are central to the deontological approach, as they determine whether or not business decisions are ethical or unethical. Only when business people act from duty do their actions have moral worth (Shaw, 2008). Shaw argues that when people act only out of feeling, inclination, or self-interest, the action has no true moral worth even if that act may be identical with ones that spring from a sense of duty. A sense of duty, which is based on reason, requires that businesspeople are driven by honesty and fairness. Moral reasoning, therefore, is fundamental for revealing principles that motivate people to engage in acts which are desirable and beneficial. Immanuel Kant, the German philosopher (1724-1804), was instrumental in articulating the non-consequential approach. He set three conditions for this approach (see Shaw, 2008 for details): rules do not depend on circumstances or results and do not permit individual exceptions; humans must not be treated as means to ends; and action has a moral worth only if there is a desire to do the right thing for its own sake.

\section{Virtue Ethics}

Unlike deontological and teleological approaches, which focus on rules and guidelines that we ought to follow or on decisions to be made, virtue ethics is concerned with the type of person we should be in the context of our relations with others and our positions in society. It divulges the traits that are essential for engaging positively in the world around us. Virtue ethics is related to dispositions that a person displays in relationships and attitudes and is embedded in the values and beliefs that one subscribes to. It seeks to highlight the virtues that lead to a meaningful and rewarding life. How these are acquired, developed, and evolved is part of the domain of virtue ethics. Since virtue ethics do not exist independently of the society and the environment where a person lives, virtue ethics tend to be numerous and may differ, in priorities, among societies. 
There are three key elements that represent the principles that drive those who promote virtue ethics (Murphy, Laczniak, Bowie, and Klein, 2005, pp. 31-2). These are: virtues are essentially good habits and in order to thrive they must be practiced and taught to those who are unfamiliar with the concept; admirable characteristics are most easily identified by witnessing and imitating widely acclaimed behavior; and a key to understanding virtue ethics and the discipline it requires is based on the ethic of the mean or the optimal balance of a quality that one should seek. Virtue ethics, therefore, differs from previous theories as it primarily revolves around individual character, attitudes, and other dispositions and preferences, including values and guiding norms. These qualities can be taught and acquired, which can induce business people and citizens in general to behave in an ethical way. Identifying these virtues becomes essential to ensure that those involved in market decision making are not only familiar with these virtues but also internalize them.

In the context of Islamic thinking, the question that might arise is, "Are these theories relevant and if so which theory or combination of theories is appropriate?" The point that should be made is that the above business ethics theories have attracted different followers and advocates. Their applications in the business world validate or refute some of their premises. The popularity of each under certain circumstances may not reflect wide acceptance or unqualified validity. This might be the reason that different cultures may take issue with certain elements of each theory or combination of theories. In Islamic thinking, ethics is not a subject that is taken lightly, but it is looked on as a foundation for a just society and for the enrichment of the faith. Ethics is characteristically linked to faith. Thus, it has been addressed extensively both in the Quran and the sayings of the Prophet or Hadith. Both sources provide a general outlook for understanding ethics and what is required for individuals as citizens and members of organizations in order to maintain responsible and morally driven conduct.

Both sources, the Quran and Hadith, basically constitute religious illustrations and instructions for the faithful and foundations for relationships and conduct, whether in the marketplace or general life. They are not intended to directly offer theoretical reasonings and outlooks. Nevertheless, they provide a genuine reference for theoretical formulation. In reviewing both sources, there is an emphasis on outcome, intention, and character as a basis for judging whether an act is ethical or not. To have an understanding of this; sample documenting instructions offered in the Quran and the Hadith are presented below.

The Quran (16:34) warns believers of the outcome of unethical behavior admonishing, "But the evil results of their deeds [overtake] them" and (30:41) "Mischief has appeared on land and sea by [reason] what the hands 
of men have earned." While these sayings focus on outcome, there are also instructions that underscore the significance of intention (74:18), "For he thought and he determined" and virtues (17:84) "Everyone acts according to his disposition." The Prophet offers clear instructions that are relevant to secular theories in which he articulates intention as a basis for determining whether an act is ethical or not, stating, "The value of work derives from its intention," and "God does not look upon either your appearance or wealth, rather God examines your intentions and actions." And though the Prophet instructs that "Work is judged by its outcome," he elaborates further when he asserts that sincere intention is a prerequisite: "Work is contingent upon intention and to each according to his intention." Furthermore, having a disposition to serve and help others goes hand in hand with intention and in judging whether the act is ethical or not: "The best people are those who benefit others" and "God loves those who benefit others." Of course, benefits take place only when there is an action and when a person is driven by no other interests except a desire for creating value that benefits self and others. This is the reason that the Prophet insists that "God examines your intentions and actions," adding that "God does not accept any claim without action and no claim or action without intention" (quoted in Al-Maki, 1995, p. 308). That is, there is a dialectic relationship between disposition of an individual and intention and action. The first two are essential for an ethical outcome.

Like other early Islamic jurists and scholars (e.g., Al-Mawardi, Al-Șâbi, Al-Shatibi, etc.), Abu Talib Al-Maki elaborated on virtues, good outcome, and intention. However, he gave the latter a special place when he stated that intention is "an act of the heart, a prerequisite for action, and constitutes the beginning of it" (p. 313). And since intention is in the heart and no other person knows about it, reward is always multiplied. Furthermore, intention is treated as a condition for good work, thus, no work can be considered ethical without good intention. An ethical act by nature is purposeful conduct and, therefore, there exists a harmonious relation between intention and outcome. Al-Maki explained that intention encompasses two elements: the exact aim of the heart toward work and sincerity. True sincerity, for him, manifests an absence of predisposition to follow desire and hypocrisy. As he stated, "sincerity without work is better than deceitful work" (p. 310). That is, the goodness or badness of any action is the result of honest or bad intention.

In terms of virtue ethics, the Quran specifies three general virtues (3:104): "Let there arise out of you a band of people inviting to all what is good, enjoining what is right, and forbidding what is wrong: they are the ones to attain felicity." Islamic tradition, however, elaborates on ten virtues needed for ethical action. These are: capacity to reason, sound faith, knowledge, 


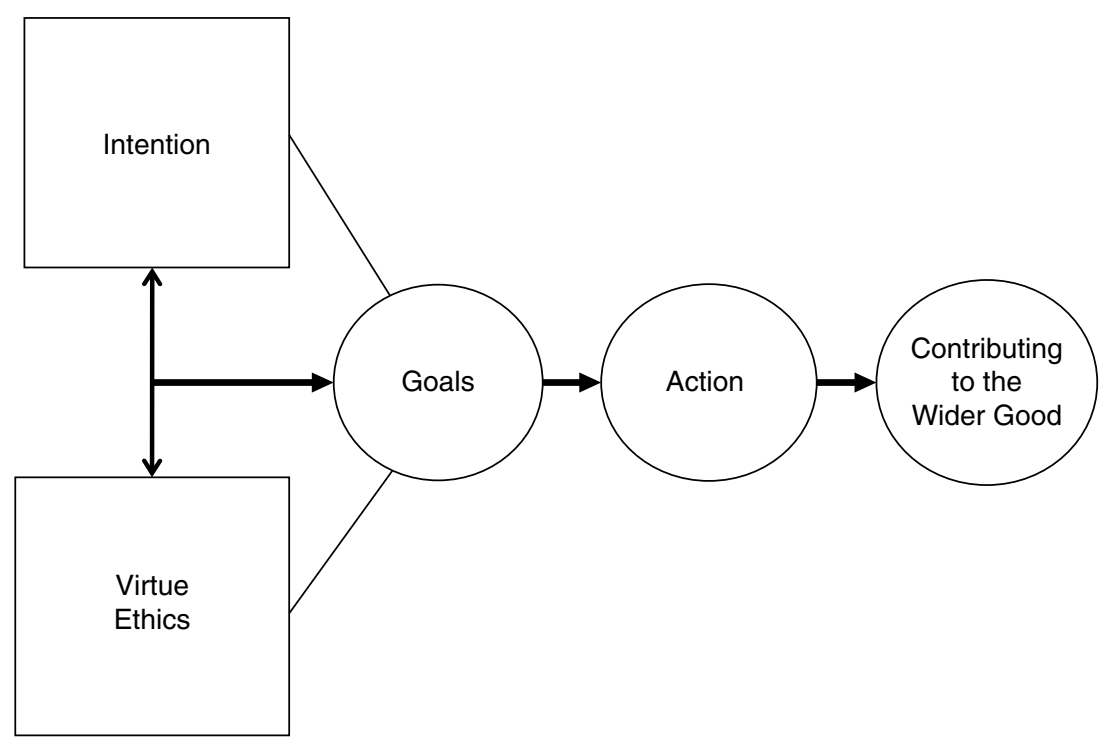

Figure 1.1 The interplay of factors that lead to wider good

forbearance, generosity, adherence to accepted custom, righteousness, patience, thankfulness, and flexibility (quoted in Al-Mawardi, 2002, p. 28). Those with these qualities are gifted with good intention and their actions veer toward serving society. While there is a wide range of virtues, Muslim scholars agree that those who are driven by interests beyond the self are more likely to engage in pursuing goals that deepen commitment to the betterment of society and to a wider sharing of benefits (see Figure 1.1). Nevertheless, the processes that translate goals into actions must be ethical and deemed so by being consistent with serving public interests. There are four means that Muslim scholars have identified (see Al Mahami, 1987, p. 549):

1. means that lead to disrepute are prohibited and must not be used,

2. means for obtaining a permissible act that leads to disreputable action are prohibited,

3. means for a permissible act that is not intended to be disreputable but often leads to it, with the resultant harm being more than the benefit is prohibited, and

4. means for obtaining a permissible act that might lead to disrepute but a resultant benefit is more likely than harm is lawful.

Al-Mawardi (2002, pp. 5-6) illustrated the linkage between intention, outcome, and benefits to society when he stated: 
The importance of a goal is characteristically linked to the significance of the outcome; the magnitude of its consequences is measured by the created benefit, and the priority given to it is contingent upon this benefit, and the care given to it determines how its fruits should be collected. The most important and the most beneficial and useful affairs are those which serve religion and life and by which in this world and the hereafter order is ensured. This is because the righteousness of religion leads straight to worship and the enhancement of life makes happiness widespread.

As indicated in Figure 1.1, in Islamic thinking, goals differ based on personality (virtue ethics) and intention or motivation (duty). Furthermore, while ethics generally explains what should be done, Islamic ethical instructions seek to change behavior in the marketplace and life. Changing conduct takes priority. In fact, the Quran gives examples of certain wrongdoings and sanctioned behavior with the hope that the faithful will observe and pursue righteousness. In terms of personalities, the Quran articulates dispositions of both those who do the right thing and those who are driven by pleasure. Before specifying these personalities, it should be mentioned that the underlying assumption of human needs in Islam is that human beings are complex and dynamic creatures. That is, they are born to strive, to weigh the consequences of vice and virtue, and seek and reach perfection. They have various choices and options in life. These choices have consequences beyond immediate self-interest. Therefore, people of the faith are reminded that they should view their actions in a broad context. The Prophet Mohamed once said, "One has an obligation toward God, self, and family; give due attention to each" (quoted in Glaachi, 2000, p. 59). In Islam, physiological, economic, and spiritual needs are not hierarchically arranged. Rather, they are considered simultaneously. The consideration, however, is influenced by intellectual insight, aspiration, and emotion. Being able to attain a balance in satisfying these needs is a virtue. The Quran (28:77) instructs Muslims to "seek through your wealth the gains of the hereafter without ignoring your share of this life." The Quran, therefore, describes a balanced personality where considerations for this life are not artificially separated from working toward pleasing, fearing, and serving God by acting responsibly and benefiting others.

\section{LEVELS OF EXISTENCE}

There are four levels of existence. These levels are in a state of flux and dynamism. People are endowed with mental faculties and a free will to decide what is good for them and their surroundings. That is, people have several options and priorities in life. Choices and priorities are shaped by 
upbringing, social and economic constraints, knowledge, and perceived and actual opportunities. The Quran specifies and details the levels of existence (e.g., 12:53; 75:2; 89:27-30). The Quran, too, clarifies not only the circumstances that shape the evolution and existence of each level, but also the conditions that induce changes and progress. That is, the psychology of a healthy person changes according to their level of existence. At each particular level, a person exhibits beliefs, values, attitudes, and behaviors corresponding to that stage. As conditions change, the person may progress or regress to a new stage. Subsequently, his/her dispositions, aspirations, values, and behaviors are expected to change. Below is a brief discussion of each in terms of intention and ethics.

\section{Sawala (A Passion for Temptations)}

At this level, a person's soul prompts him/her to follow only their desires and to shy away from enlightenment. For example, in the story of Moses, the propensity to evil made Samiri lead Moses's people astray in his absence. When Moses asked Samiri what he had done: "Samiri told Moses, 'I had the skill [of carving], which they did not have. I followed some of the messenger's [Moses's] traditions, but I then ignored them. Thus, my soul prompted me (to carve a golden calf with an artificial hollow sound)" (20:96). Samiri acted in a way that eventually inhibited him from serving the interests of the people and optimized his interests. The fourth Caliph, Imam Ali (AD598661), described the nature of a person at this stage (1990, pp. 715-16):

When in doubt, he follows his passions instead of reason and even though he is
certain that happiness lies in doing what is good, he disregards this. ... When
there is opportunity to satisfy his passion, he enthusiastically follows it, but he
delays seeking forgiveness. If he experiences difficulties, he loses his patience. . .
He is full of talk but avoids action. He competes for things that are insignificant
and ignores things that are beneficial. He considers work that is of significance
a burden and that which satisfies his passion is of great importance. . . He is
quick in criticizing others but lavishly compliments himself. Time that he spends
with the rich for pleasure is more important to him than spending time with the
poor remembering God. . . He fears those people whose actions are not sanc-
tioned by God but does not fear God in his dealings with people.

The primary preoccupation at this stage is with pursuing self-interest. That is, people may possess the mental capacities for differentiating between good and bad, but they lack the capacity to integrate their needs with the rest of their surroundings. Their obsession with self-interest inhibits them from engaging responsibly in actions that serve others, leading to output that is intentionally unethical. That is, temptations overwhelm and blind them from addressing that which is good. 


\section{Ammara (The Prone-to-Evil Psyche)}

This is a stage where a person is aware that their soul induces them to do bad things and yet offers no resistance to it. At this level, the human soul is a burden with desires and temptations. The Quran (12:53) depicts this personality stating, "Yet, I do not absolve myself (of blame): the human soul certainly incites evil, unless my Lord bestows His mercy." In this context, a person is inclined intentionally and perhaps contrary to self-interest, to engage in wrongdoing. Nevertheless, a person at this stage is willing to confess mistakes under pressure or when he/she understands that conditions are no longer conducive to serving his/her interest. Perhaps this manifests a lack of internalization of the spiritual beliefs. Therefore, intentionally, ethical considerations are not pursued primarily for the sake of a higher goal. At this stage, a person is aware that for actions there are consequences, be they rewards or punishments. However, because the desire for passion overwhelms wisdom, the person is inclined to follow desires.

\section{Lawama (Self-Reproachment)}

At this stage, Man is conscious of evil. There is a struggle between good and evil and Man seeks to repent in order to achieve salvation. In sections 75:2 and 75:14-15, the Quran explains the conflicts at this stage of human development: "And I swear by the self-reproaching soul" and "Nay, man will be evidence against himself, even though he were to put up his excuses." Thus, the Lawama soul either drives a person toward good and perfection or toward evil action and aggression. In the latter, the person is not inclined to pursue good actions.

People make choices in life and have to live with the consequences, whether these consequences are good or bad. Accordingly, a person at this stage is subject to a continuing internal struggle, hesitation, and frustration. Unlike the preceding stages, the inclination to follow one's desires at this level is not unbridled, as one's will seeks to constrain self. If the will to engage in positive activities overwhelms desires, a person may reach a sense of spiritual fulfillment and contribute to the betterment of society. Intentions are closely pondered and actions taken that are thought to ease life for others, while helping self. This is ensured when a person has clarity of mind. Individuals at this level are generally sensitive to moral and ethical standards, are aware of their weak tendencies, try to resist selfish pursuits, are troubled when things go wrong, and consider what happens to them a consequence of their own choices. 


\section{Mutamainna (The Righteous)}

This is the ultimate point in human development. At this level, the mind is perfectly in tune with good deeds and a person realizes complete satisfaction and self-actualization. The Quran (89:27-8) says, "To the righteous soul will be said, 'oh soul come back thou to thy Lord, well pleased (thyself), and well-pleasing unto Him."' Muslim scholars describe this person as one who is content and satisfied with what he/she has, regardless of "abundance or scarcity, prosperity or shortages, prohibitions or permissiveness. It is content without any doubt and does not change heart or deviate from the straight path, and is not fearful during terrifying events" (Al-Jasmani, 1996, p. 16). The fourth Caliph, Imam Ali (1990, p. 475), elaborated that a person at this stage is tempered with magnanimity and practices what he preaches, stating:

Good deeds are anticipated of them and bad ones are impossible. . . He forgives those who inflict injustice upon him, gives to those who deprive him, and reaches out to those who desert him... . He is calm in the face of calamities, patient when challenged by adversity, and thankful during times of prosperity. He does not violate the rights of those whom he dislikes and does not blindly favor those whom he prefers. He admits the rights of others before there is a judgment against or for him. He is not negligent with what he has been entrusted. ... He does not ignore a fact when reminded of it. He does not speak ill of people ... and does not rejoice when others experience misfortune.

According to Shariati (1979), people who reach the Mutamainna stage tend "the earth ... with the power of their industry . . create a life overflowing with abundance, enjoyment and prosperity" without suspending feeling and all sense of value. They are those in whom the peculiarly human capacity "to perceive the spirit of the world, the profundity of life, the creation of beauty, and the belief in something higher than nature and history" has not been weakened or paralyzed. At the Mutamainna stage, a person is responsible and committed to ethical conduct. His/her intentions and actions are one and the same.

The above four levels of psyche are descriptive of personal values and life-styles. The domination by a particular psyche determines the intensity and priority of human needs and behavior. At each level, a person is conscious of his/her actions. This is significantly different from Sigmund Freud's model. Freud, one of the pioneers in studying human psychology, suggested that people, due to their differences in personality, deal with their fundamental drives differently. He postulated that there is a battle between two parts of the soul, the "It" or id (unconscious part) and the "I" proper or the "ego" (an individual's picture of physical and social reality) and the 
"superego" (storehouse of an individual's values). Freud views the "It" as the hidden or essence of the soul and the "I" as the open and apparent part of the soul. The "It" and "I" are destined to be continuously at war and only "compromise, but never harmony, [can] be achieved between them" (Wilber, 1999, p. 583). This is not similar to Islamic thinking. In Islam, a person is free to choose his/her direction in life, depending on the psyche at a particular stage. The constant struggle or war within oneself, as Freud suggests, is found in the second (Ammara) and third (Lawama) levels. Even at these levels, the inclination to progress toward "goodness" and "perfection" is always an aim. This is contrary to Freud's assumption that the urge to do things right is not considerably weaker, relative to the urge to do evil. At the last level (Mutamainna), people appear to display no uncertainty about their choices in life. The Quran (49:15) explicitly refers to this level by stating that believers are the sincere ones who have "never doubted."

Table 1.1 presents a model of personality and disposition to engage in ethical behavior. It can be seen that the two extremes Sawala and Mutamainna represent two contradictory tendencies in expected outcomes. The first does not seek an ethical result, though it might take place unintentionally. On the other hand, a person who reaches the Mutamainna stage is driven by the desire to serve others and he/she engages in ethical activities that are destined to lead to the greatest benefit. At the stage of Ammara, the prospect for engaging in ethical conduct is there, however, the likelihood is not high. In contrast, at the Lawama level, the possibility of attaining ethical results is relatively much higher. This is because individuals at this stage are aware of their duties and what should be done to rectify wrongdoing.

Table 1.1 Level of existence and ethical behavior

\begin{tabular}{|c|c|c|}
\hline Level of Existence & Preoccupation & Ethical Inclination \\
\hline Sawala & $\begin{array}{l}\text { Passionate pursuit of desires, } \\
\text { irrespective of the concerns of } \\
\text { others. }\end{array}$ & Is not a concern. \\
\hline Ammara & $\begin{array}{l}\text { Aware that his/her actions } \\
\text { might harm others, } \\
\text { nevertheless, inclination is high } \\
\text { to follow desires. }\end{array}$ & $\begin{array}{l}\text { Ethical output is not } \\
\text { pursued for its sake. }\end{array}$ \\
\hline Lawama & $\begin{array}{l}\text { Concern with satisfying } \\
\text { one's needs and contributing } \\
\text { something useful to others. }\end{array}$ & $\begin{array}{l}\text { Ethical conduct is } \\
\text { sought. }\end{array}$ \\
\hline Mutamainna & $\begin{array}{l}\text { Serving society and spreading } \\
\text { benefits. }\end{array}$ & $\begin{array}{l}\text { Ethical conduct is a } \\
\text { given. }\end{array}$ \\
\hline
\end{tabular}


The point is that ethical conduct is shaped by the surrounding environment, expectations, and the personality of actors involved. Not all actions lead to ethical behavior. Though it is desirable that the greatest number of people gain benefits, this is only possible when the Mutamainna stage of development is common. In the other stages of personality, there is a constant struggle to create the right conditions where people become more conscious of their role and have the capacity to internalize ethical norms.

\section{ETHICAL FOUNDATIONS AND ASSUMPTIONS}

Al-Shatibi (2011), a Muslim jurist (died 1388), identified five types of rules regarding actions and legality: mubah (permissible), wajib (obligatory), mandub (recommended), mukruh (discouraged), and haram (forbidden). The last two categories (discouraged and forbidden) are within boundaries where the rules are clear and thus any activity within these two categories must be avoided, as the possibility of violating ethical standards is high; for example, gambling, engaging in selling and buying alcohol, charging interest, hoarding commodities, indecent advertisements, and trading in counterfeit goods.

In the case of what is permissible, there is no demand for exclusion or commission and it is left up to the person to choose. Furthermore, AlShatibi argued that the permissible category is equal in strength to that of the obligatory and recommended categories, in so far as none of these entail a demand for omission. When the Prophet Mohamed was asked how to cultivate reasoning, his answer was, "Avoid the forbidden, perform obligatory duties, you acquire reason. Seek to go beyond what is required and obligatory in doing good things, your capacity to reason improves and you get closer to god" (quoted in Al-Mawardi, 2002, p. 28).

According to Carney (1983), the fivefold model of duty in Islam is a blend of duties deriving their force from commandments, principles, laws (required and forbidden categories), and acts of virtues deriving their persuasiveness from an attractive ideal of human nature and translated into unique kinds of duties (recommended and discouraged categories). When Carney contrasted the threefold Christian model (recommended, discouraged, and permissible) with that of the fivefold Islamic, he concluded that the fivefold model of obligation appears to "more adequately respond to our moral experience than does the threefold model" (p. 167).

Ethical actions in Islam, however, cannot be understood without a familiarity with three philosophical logics: Maslaha Aamah, moderation, and ehsan. All three constitute the foundations for ethical conduct and responsible action. They represent the theoretical framework that 
guides the faithful in conducting their affairs. This framework not only sets Islamic ethical perspectives apart from the other two monotheistic religions, Christianity and Judaism, but also makes it easy to delineate the purpose and scope of business ethics. The first, Maslaha Aamah, situates the interests of the people at the heart of business ethics. This is because everything on earth is created to serve people. The Quran (45:12-13) states, "It is God who has subjected the sea to you that ships may sail through it by His command that ye may seek of His bounty and that ye may be grateful. And He has subjected to you as from Him all that is in the heavens and on earth: behold in this are signs indeed for those who reflect." While Christian ethics, especially Protestantism, asserts that love is the way to absolve sins and puts "people at the center of concern" (see Fletcher, 1966, p. 50), it differs from Islamic ethics not only in promoting that ends justify the means, which is outlawed in Islam, but also because Islamic instructions and the logic of Maslaha Aamah underscore that everything in this world is created to serve people.

Indeed, the centrality of human beings and the belief that God's approval is contingent on benefiting others makes the relationship between self and societal interests a subject that goes beyond intellectual exercise and is a practical aim for those who seek to observe the principles of the faith. This is the very reason that Islamic instructions underscore the necessity of acquiring knowledge to behave ethically, especially in the marketplace. The Quran (29:43) states, "And such are the parables we set forth for mankind, but only those who understand them have knowledge," while the Prophet observes, "Goodness is a habit... . Whomsoever God intends to do good, He boosts his knowledge in religion" and "The most excellent in my community are those who attain knowledge" (quoted in Al-Mawardi, p. 53). Imam Al-Ghazali (2006, died 1111, p. 504) stated, "Be a knowledgeable person who works and you will reach your highest aim."

Knowledge, however, is worthless if it is not utilized in the service of the people. Al-Mawardi (2002) argued, "There is no benefit from knowledge if it is not translated into action. As some learned people indicated, the fruit of knowledge is put to the service of the people. ... The best knowledge is the one that generates benefit. ... A perfection of knowledge is applying it" (p. 122). The essence of knowledge should be put in the service of people and the best of knowledge is that which eases people's lives and facilitates their progress. This is because serving people is the primary end of any ethical conduct. As the Prophet observes, "The closest people to God are those who serve people" and "whatever the believers consider a good act, then it is good in the eyes of God. And whatever they deem bad, God treats as bad" (quoted in Al-Maki, 1995, p. 551). The Prophet, too, instructs people to appreciate others and be kind to them stating, "He who 
does not thank people, does not thank God." The second Caliph, Omer, elaborated on this explaining that "If God likes a person He guides him to be kind to others. Your position in the eyes of God is contingent upon your stance toward people. Whatever God's feelings towards you, is exactly what you tender to people" (quoted in Ibn Abed Raba Al-Andelesy, 1996, died 985, vol. 2, p. 155).

Thus, the logic of Maslaha Aamah implies that serving and benefiting people are preconditions for God's approval of any action. Maslaha Aamah encompasses two elements: acquisition of benefits and repulsion of harm. Both elements are needed to judge whether an act is ethical or not. Most Islamic scholars argue that applying these two elements leads to the enhancement or advancement of societal welfare. This is because all actions are judged right or wrong upon the serving of public interests (see Al Mahami, 1987, p. 556).

The second logic that represents an outlook and orientation that guides action is moderation. This logic implies seeking a Middle Way. According to Hofstede (1999, p. 43), the rationale for the Middle Way "is that any virtue becomes a sin when extended too far." This is precisely what the Quran (25:67), expressed in terms of spending, states: "Those who, when they spend, are not extravagant and not niggardly, but hold a just balance between those extremes. ..." Furthermore, in its instructions to believers the Quran (2:143) reminds them to behave justly and act according to what was intended for them: "Thus we have made you a middle-way nation."

The significance of moderation is that it not only enables a person to be steadfast and avoid extreme positions, but it also minimizes troubles and enhances reflection and rethinking of those matters that are important for personal growth and societal cohesiveness. Imam Ali (1990, p. 624), in his letter to his governor in Egypt, elaborated on this when he instructed him "let your preference in all matters be the most righteous (modest) and one that encourages justice and has the approval of the majority of the constituency." In addition, he stated (1990, p. 122), "All extremes lead to nowhere. Only the middle way is the right way. . . It leads to safety and desired results." AlAndelesy (1996, vol. 2, p. 199) argued that "The best way is the Middle Way." Likewise, Al-Deinori (1999, p. 381) reported that "Most ethical work is associated with great moderation." This conveys that moderation is an essential foundation for ethical conduct and morally driven actions.

In business conduct, Islamic ethics often highlight the significance of moderation in spending, consuming, leadership, and human resource management. While spending is specified above, and in Chapters 6 and 8, in terms of consumerism, the Quran (7:31) instructs, "Waste not by excess, for God loveth not the wasters." Similarly, the Prophet stated that "He who is prudent in spending will not be dependent on others." 
In the context of leadership, the Prophet stated, "Be gentle (to the people) and be not hard (on them), and make (them) rejoice and do not incite (them) to aversion" (quoted in Muhammad Ali, p. 404). Likewise, the fourth Caliph, Imam Ali (1990, p. 402), asserted, "The best people are those who keep to the middle ground. Those are the ones you should follow." And Al-Andelesy (1996, vol. 3, p. 61) stated, "Do not be too lenient so as to be taken advantage of and do not be so rigid that people stay away from you. Being in the Middle Way is the safest action." In terms of human resource management, the Prophet instructed, "Whoever has his brother under his control should feed him from what he eats and should give him clothes to wear from what he wears. Do not impose on them a task which should overpower them, and if you impose on them a task, then help them (in doing it)" (quoted in Muhammad Ali, 1977, pp. 383-4). Thus, in business conduct, Islamic ethics underscores the importance of moderation in building a sound organization and in creating a solid foundation for morally driven conduct. These will be addressed in detail in the chapters that follow.

The third element of the theoretical framework for ethical action is ehsan. The philosophy of ehsan stems from a recognition that humanity, in order to survive and thrive, has to be inclusive and tolerant, responsive and appreciative to changes and emerging needs. The concept of ehsan is the embodiment of goodness and generosity in interaction and conduct, be it on a personal or organizational level. As a projection of goodness and generosity, ehsan practically and spiritually encompasses mercy, justice, forgiveness, tolerance, and attentiveness. This means the term conveys a much broader meaning than any of its components, and in the marketplace it represents a philosophical logic that guides participants of the business exchange function to observe the rights of each, while attempting to ease difficulties for others. In a sense, the logic of ehsan in its meaning goes beyond what existing stakeholder orientation advocates. For example, Al-Mawardi (2002, p. 169) quoted Sefan ibn Ayneeha (an early Muslim scholar) saying, "Justice means that what is declared and what is kept secret are identical... Ehsan conveys that what has been kept secret is much better than the declared deed." Al-Maki (1995, p. 561) viewed it from a different angle stating that "Justice is to take what is right for you and give what is right to others. Ehsan is to absolve part of your right and give more than what you owe to others to be among those who do the right things." Though the end results of both views are the betterment of society, the implication of ehsan in the marketplace is far reaching and certainly leads to a functional and ethical exchange in the market. And since ehsan focuses on relationships among actors of the exchange function, judging whether any action or conduct is right or wrong must stem primarily from 
the assurance that no market participants are hurt or their rights or those of the society as a whole are ignored. In other words, the philosophy of ehsan does not compartmentalize the rights of market actors as rivals and as allies but as significant members of a worthy and religiously sanctioned cause. This implies that interactions in the marketplace are treated primarily as relationships among equals who seek to offer benefits beyond self and immediate interests. The Quran (49:13) states, "The noblest of you in the sight of God are the best of you in conduct."

Accordingly, business ethics is defined as principles and rules that govern individuals' and organizations' conduct in the marketplace. It goes beyond legal and social requirements to include furthering public interest and espousing the philosophy of ehsan. Figure 1.2 presents a framework for producing ethical conduct. The elements of the framework include the foundations (commitment to meeting public interests, moderation, and the philosophy of ehsan) and the prerequisites for ethical actions (good intentions and virtue ethics). Without a concern for societal welfare and a disposition toward ehsan, neither good intentions nor virtues will be cultivated. Thus, engaging in processes or methods that are morally driven and lead to desirable or ethical behavior becomes ordinary behavior. That is, in Islamic thinking, the intent, means, and end results must be consistent and

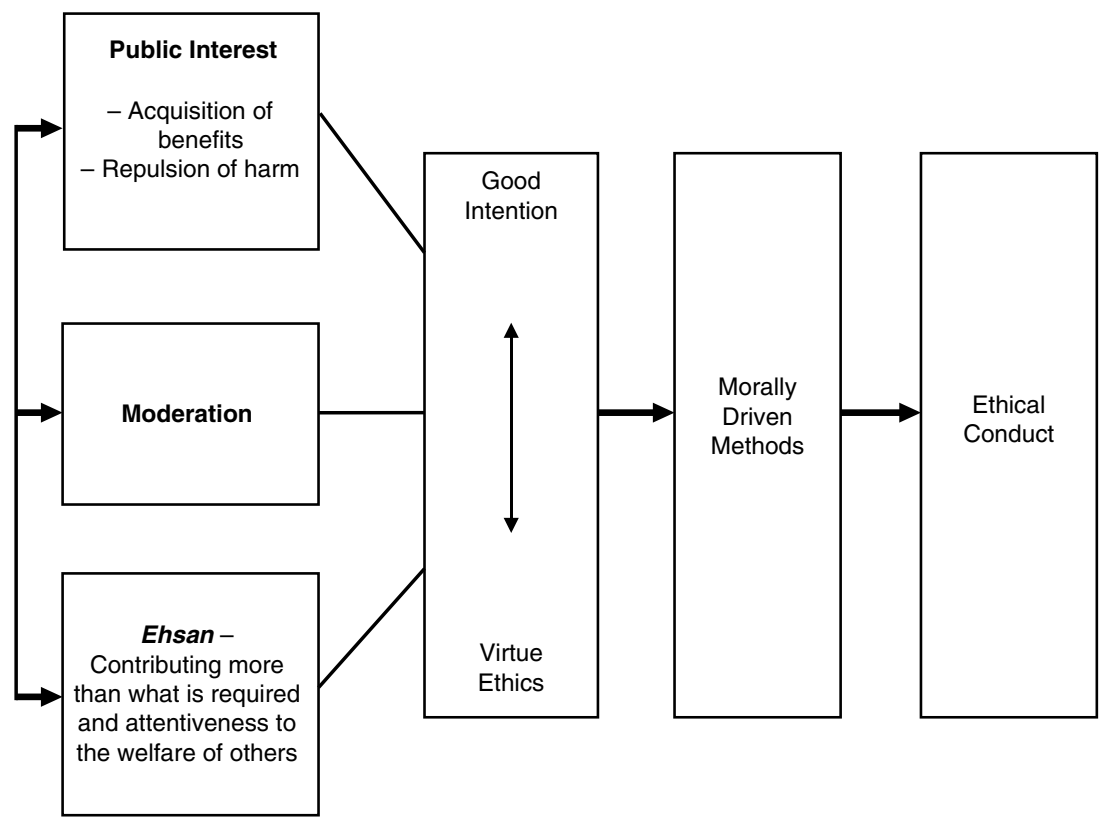

Figure 1.2 Theoretical framework for ethical conduct 
moral. It is important to note that the logic of ehsan in connection with the element of public interest (generating the greatest benefits, rejection of harm, and promoting the logic of moderation) offers, in theory, a standard of conduct that exceeds what is expected by law or the existing market capitalism ethos.

\section{CONCLUSION}

This chapter provides an overview of business ethics in Islam. Ethics, in general, and business ethics were defined. The chapter then offered a brief introduction of existing theories on ethics and presented an Islamic perspective on ethics. It was argued that Islamic instructions offer an integrated framework within which to address business ethics. In this regard, a model for providing greater good to society was introduced.

The chapter, too, discussed the fivefold model of duties. These duties are specified as permissible, obligatory, recommended, discouraged, and forbidden. While business activities are encouraged, certain other engagements are either forbidden or discouraged. In addition, there are some activities which are permissible but under certain conditions they may be situated as doubtful and, thus, should be avoided.

Finally, the chapter presented a model for ethical conduct. The theoretical elements, public interests, moderation, and the logic of ehsan, were identified along with the prerequisite components, intention, and virtue ethics. All lead to selection of means that are in harmony with serving societal interests and producing desirable behavior. 